\title{
The Introduction of SRI in Uttarakhand, India
}

Technopolitical Mythologies and Sociotechnical Flexibility

Debashish Sen, Harro Maat, Dominic Glover and C. Shambu Prasad

\section{(2) OpenEdition}

\section{Journals}

Electronic version

URL: http://journals.openedition.org/anthropodev/595

DOI: 10.4000/anthropodev.595

ISSN: 2553-1719

Publisher

APAD - Association pour l'anthropologie du changement social et du développement

\section{Printed version}

Date of publication: 1 December 2017

Number of pages: 100-126

ISBN: 979-10-93476-05-6

ISSN: 2276-2019

\section{Electronic reference}

Debashish Sen, Harro Maat, Dominic Glover and C. Shambu Prasad, «The Introduction of SRI in

Uttarakhand, India », Anthropologie \& développement [Online], 46-47 | 2017, Online since 01 June 2018, connection on 19 April 2019. URL : http://journals.openedition.org/anthropodev/595 ; DOI : 10.4000/ anthropodev. 595

La revue Anthropologie \& développement est mise à disposition selon les termes de la Licence Creative Commons Attribution 4.0 International. 


\title{
The Introduction of SRI in Uttarakhand, India
}

\section{Technopolitical Mythologies and Sociotechnical Flexibility}

\author{
Debashish Sen, Harro Maat, Dominic Glover and C. Shambu Prasad
}

Cet article discute les représentations du système de riziculture intensive (SRI) - un ensemble de principes agronomiques promus comme méthode de riziculture durable - vis-à-vis de trois notions clés du développement agricole: rendements, durabilité et adoption par les agriculteurs. Nous soutenons que c'est par le biais d'affirmations exagérées (qu'elles soient positives ou négatives) sur le lien entre SRI et ces trois notions, que le SRI a acquis des attributs mythologiques. Contrairement à l'interprétation populaire qui voit dans les mythes "des fausses croyances", nous adoptons une perspective anthropologique sur les mythes en les conceptualisant comme des récits qui créent du sens et motivent l'action. C'est par ces récits que le SRI a été associé à des discours dominant le secteur du dévelop-pement sur la sécurité alimentaire et l'agriculture durable et, ce faisant, passant sous silence les processus complexes qui déterminent les pratiques rizicoles et réduisant le SRI à une solution technopolitique. Nous soutenons que ces visions restrictives du SRI (et des technologies en général) contribuent à l'écart entre les mondes de la science et de la politique, d'une part, et les réalités des agriculteurs, d'autre part. À l'aide d'une étude de cas sur les changements dans les pratiques d'ensemencement et de transplantation de cultivateurs de riz dans le nord de l'Inde, nous montrons que les agriculteurs utilisent aussi des récits mythologiques, mais de manière beaucoup moins contraignante. Les récits de développement en tant que mythes lau sens anthropologique) peuvent aider leurs communautés à faire face au changement, sans qu'ils soient basés sur des solutions prédéfinies.

This paper situates representations of the System of Rice Intensification (SRI) - a set of agronomic principles promoted as a method for sustainable rice cultivation - in the context of three key values in agricultural development: high yields, sustainable agriculture and widespread adoption by farmers. We argue that 
overstated claims in relation to these values, positively by promoters and negatively by critics, endowed SRI with mythological attributes. In contrast to a popular understanding of myths as false beliefs, we adopt an anthropological perspective on myths as narratives that create meaning and motivate action. The mythological associations of SRI have connected it to overarching development narratives about food security and sustainable agriculture, which implicitly reduce the complex and intricate processes of rice cultivation using SRI techniques to a neat, technopolitical fix. We argue that these simplistic framings of SRI (and technology more generally) contribute to the gap between the worlds of science and policy on one hand and farmers' realities on the other. Using a case study of changes in the seeding and transplanting practices of rice cultivators in northern India, we show that farmers also use mythological narratives but in a far less constraining manner. Development narratives as myths (in the anthropological sense) can guide people and their communities in dealing with change without determining clear-cut solutions in advance.

\section{Introduction ${ }^{1}$}

The history of the Green Revolution demonstrates how donors, policy makers and politicians become attracted by the potential of new agricultural technologies to achieve general humanitarian goals as well as specific geopolitical interests (Perkins, 1997). IR8, the first modern rice variety released by international research in the late 1960s, was soon

\footnotetext{
${ }^{1}$ This paper is based on PhD research carried out by Debashish Sen under the guidance of Prof. Paul Richards, C. Shambu Prasad, Harro Maat and Dominic Glover. Fieldwork and data collection were performed by Debashish Sen. The paper was written by Debashish Sen, Harro Maat and Dominic Glover based on a draft written by Debashish Sen, with advice and contributions by $\mathrm{C}$. Shambu Prasad.

The research was funded by the Dutch Organization for Scientific Research, Science for Global Development programme (NWO-WOTRO, grant number W01.65.328.00). We thank the People's Science Institute (PSI) and Mount Valley Development Association (MVDA); field assistants Bhupendra Bartwal, Dinesh Jayada and Pushpa Bhandari; the farmers of Phalenda, Thayeli and Dakhwangaon; Prof. Paul Richards, Dr T.M. Thiyagarajan, Dr M. Kumar, and Dr Willem Stoop.
} 
named 'miracle rice' by its promoters, even though breeders of IR8 were reluctant to sell science as superstition (Cullather, 2010: 173). Mythological attributions conferred on agricultural technologies, this paper argues, are an effect of the way a technology becomes embedded in politicaleconomic discourse and attached to overarching development narratives. In contrast to a popular understanding of myths as false beliefs, we adopt an anthropological perspective on myths as narratives that create meaning and motivate action. They represent key features of everyday social practice and help people to make sense of sociotechnical change. This social-anthropological notion of myth offers a more insightful and useful perspective than the popular, largely pejorative meaning to explain how technology and myth are linked.

The popular understanding of myth is a widely held but questionable and probably false belief; myths are fantastical tales, not to be taken seriously but narrated for entertainment only. Anthropologists take a different view. Like magic and rituals, myths function as cultural tools that aid perception and sense making, by providing a common framework for dealing with issues that matter to a community. Mythological narratives convey moral codes and serve as background frameworks that give meaning and purpose to particular rituals (Douglas, 2002; Kuper, 1999). Rituals associated with farming practices create a cultural framework for the distribution of shared responsibilities among farmers and rural communities in order to ensure that agricultural tasks are performed in the proper way and the right time (Lansing, 2009).

A prominent connection between technology and myth emerges in general development narratives and public discourse, where politicians, bureaucrats and investors regard a technical fix such as IR8 as the principal solution for complex social problems. The argument developed in this paper is that a technical fix, when introduced and discussed in global discursive contexts, gets loaded with moral codes that relate to key values of the global community. A specific connection between technology and development narrative emerges, which we describe here as technopolitical mythology. The moral message is that the technology should be adopted in order to safeguard the overall wellbeing and prosperity of the (global) community. Technopolitical mythologies emerge around a wide variety of technologies and in various global discourses. In this paper we focus on 
technopolitical mythologies relating to agricultural improvement for international development. Technopolitical mythologies represent a specific genre of technical fixes, the latter referring to a more general reframing of social problems as technical problems (Scott, 2011). The combination of myth-like properties attributed to a technology and the strong focus on a singular technological solution or trajectory conceals or suppresses alternative development pathways (Stirling, 2008).

We argue that technopolitical mythologies typically emerge within global development discourse, whereas in local contexts the connection between myth and technology has a different dynamic. In agricultural practice technology is connected to myth through rituals associated with farm operations. Changes in technology may interfere with ritual practices and mythical beliefs. This interference can be dealt with pragmatically by adjusting the ritual or the technology, or both. Mythological narratives convey general guidance on how to accommodate such change, often through ambiguous metaphors, within an overall social and cultural framework that focuses on bringing prosperity to individuals and the community. Hence, we argue that myths (as cultural tools) and farm operations (as mundane and practical tools) are complementary. In this paper we examine the ways in which rice cultivation technology is connected to myths through technopolitical mythology as well as practicerelated rituals. We develop this argument through the lens of the System of Rice Intensification (SRI), a cultivation method that has been portrayed in Asia and other parts of the world as a yield-enhancing and input-saving innovation in rice production, but also contested as a false narrative based on bad science (Berkhout et al., 2015; Glover, 2011b).

We describe how SRI has attained myth-like characteristics, influenced by the process of contestation between its promoters and its critics. Representations of SRI in relation to three key values in agricultural development - high yields, sustainable agriculture and wide distribution resulted in overstated claims among SRI promoters and accusations of creating false promises by SRI critics. This contestation contributed to the myth-like status by magnifying and exaggerating certain claims, both negative and positive. The claims and accusations circulated principally among researchers and development agencies and we show that they can be related to more general development narratives about changes in 
agricultural practice and technology. These framings contribute to the gap between the world of science and policy on one hand and farmers' realities on the other. Using a case study of changes in the seeding and transplanting practices of rice farmers in northern India, we show these practices were also associated with mythical stories but in a far less constraining manner. These insights contain an important lesson that development narratives, functioning as myths in the anthropological sense, may be used as guides that help people to deal with change without determining specific solutions.

We show how the three contested values of SRI - high yields, sustainable agriculture and wide distribution - relate to two broader and overarching narratives of agricultural development, one about food security and the other about sustainable agriculture. We argue that these associations help to frame SRI as a technopolitical mythology. We then look at the way rice farmers in a mountainous area of Uttarakhand, India, responded to the introduction of SRI. We show that mythological stories also guided the farmers when they assessed the kinds of practical and organisational changes entailed by the introduction of SRI. The connections between myth, agricultural practice and technology reveal a different development narrative, concerned primarily with the community's shared interest in a good harvest.

The essence of our argument is that newly introduced technologies such as SRI are assessed by farmers on their potential to contribute to improvements of existing agricultural operations, and applied in a flexible way. In the communities we studied, SRI was adjusted and reworked by the farmers to fit into the local rice farming system. The connection between SRI as a technopolitical mythology within global discourse, and SRI as a set of farming practices applied flexibly at the local level by rice growers, seems distant at first glance. Villages in Uttarakhand seem detached from the scientific disputes, media debates and abstract policy deliberations that have emerged around SRI at the international level. However, remote Himalayan villages are connected to the Indian political economy, for example through (national) regulations, ministerial programmes and trade connections. Interventions by government agencies and NGOs and other actors have direct impacts in these areas. Our paper concludes by arguing for an allegorical understanding of development 
narratives, which can be used as 'reminders' that invoke key community values, rather than devices to drive the adoption and application of new technology in a preconceived manner.

\section{SRI as technology and myth}

The System of Rice Intensification is an agro-ecological cultivation method comprising a suite of recommended crop and field management practices. The central principle of SRI is to enhance healthy growth by allowing more space for individual rice plants and optimising soil aeration, irrigation and nutrient uptake. By applying SRI practices, farmers can save on material inputs without loss of yields. Considerably higher yields are possible with SRI compared to traditional practices, and farmers can also benefit from reducing input costs, particularly through water saving. The SRI practices differ from conventional lowland (wet) rice cultivation methods in several respects. They include transplanting seedlings when they are about 8-15 days old (roughly half the usual seedling age), in a widely spaced grid pattern often specified as 25 by 25 centimetres. Farmers are advised to use much less water compared to typical fully inundated paddy cultivation, in order to create moist soil conditions that allow more aeration of the root zone. The preferred form of weed control under SRI is by mechanical rotary weeders, which churn the soil and trample weeds into the mud, adding to soil organic matter. Additional organic manure, typically composted mixtures of animal manure and crop residues, is also recommended. The combination of these practices is believed by its supporters to stimulate or exploit a synergetic effect that multiplies the individual benefit of each of the SRI principles, to produce exceptionally high yields (Uphoff, 1999, 2003, 2013; Uphoff et al., 2009, 2015; Thakur et al., 2009; Berkhout et al., 2015).

The SRI principles were first compiled in Madagascar during the 1980s by Fr. Henri de Laulanié, a Jesuit priest trained in agronomy. Laulanié founded the Association Tefy Saina to promote SRI among Malagasy farmers (Glover, 2011a). Laulanié wrote about his methods (Laulanié, 1993) but SRI was largely unknown to the rest of the world until 1999 when publications by Norman Uphoff $(1999,2003)$ and Willem Stoop (2002) began to present SRI to the scientific community. The SRI method 
was spread largely through networks of civil society and non-governmental organisations (CSOs and NGOs), facilitated by Uphoff and the Cornell International Institute of Food Agriculture and Development (CIIFAD), which Uphoff led until 2005. Many rural development NGOs have taken up SRI within their programmes and have promoted the method to an estimated 10 million farmers across 50 countries, who together are estimated to be cultivating about four million hectares of rice. SRI-related activity is present most prominently in China, India, Vietnam, Indonesia and Cambodia (Kassam et. al., 2011; Uphoff et. al., 2015).

Three claims contributed in particular to SRI's myth-like properties at the centre of a scientific controversy: super high yields, a synergetic growth mechanism, and its wide adoption by farmers. The first two claims came in for particular criticism (Surridge, 2004). More than a decade ago, SRI was fiercely attacked by some rice scientists during an episode characterised by Shambu Prasad (2009) as 'the rice wars'. Some of the critics even denounced SRI as an 'agronomic UFO' or 'Unconfirmed Field Observation' (Sinclair and Cassman, 2004). The controversy played out in part as a clash of institutions, between the alternative agro-ecological networks promoting SRI on one hand and the formal research institutes of rice science, governments and international donors on the other. However, statements from the director of the World Bank and government officials from India have supported the high yield potential of SRI (Glover, 2011b and 2014).

Crop yields are limited to a theoretical maximum known as the 'yield ceiling'. The rice yield ceiling lies in the range of 16-20 tons per hectare (Duwayri et. al., 2000; Laborte et al., 2012). Although yields within this range are occasionally measured under experimental conditions, they can only be achieved with high input costs. In 2002, Tefy Saina member Sebastian Rafaralahy (2002) first reported yields from SRI fields in Madagascar of more than 20 tons per hectare. Rafaralahy's paper did not appear in a scientific journal but the figure was cited by others in peerreviewed publications, triggering fierce responses from rice scientists who characterised such accounts as 'fantastic' or 'nonsense' (Surridge, 2004; Sinclair and Cassman, 2004; Sheehy et al., 2005). Subsequently, high yield claims from SRI continued to emerge from time to time, although very rarely at levels surpassing the yield ceiling. In India such claims have been 
made not only by SRI farmers or NGOs promoting SRI but also by government officials, and frequently reported in the (English-language) national press (Basu and Leeuwis, 2012).

The second element contributing to the dismissal of SRI as a myth (in the popular sense of the word) is the claim that the individual SRI principles operate together with a synergetic effect. Besides serving as a proposed explanation for very high yields, the synergy argument also included a methodological critique of the way field experiments are designed, in particular the focus on singular cause-effect relations in crop growth. Although testing interactions between multiple factors is possible in principle, experiments of this kind are difficult to design and perform, and the levels of uncertainty in their results are typically high. The few studies investigating the potential synergies among the SRI practices failed to provide a solid confirmation (Berkhout et al., 2015). An underlying critique about inappropriate experimental designs did not result in improved methods for studying the claimed synergies. Indeed, some of the high yield claims made by SRI promoters were based on straightforward single-factor experiments, which the synergy claim implied were invalid (Maat and Glover, 2012). These complications made it hard for SRI proponents to substantiate the synergy claims with scientific evidence. However, for the same reasons it has been equally hard to refute the synergy argument. The possible synergetic effect thus remains an unknown quantity - the kind of mystery that would not be out of place in a mythical story.

An implication of the synergy claim, which relates to the third mythological component - the contested rate and extent of SRI adoption among farmers - is the implicit framing of SRI as a fixed technology package. This follows from the argument that SRI methods can produce very high rice yields due to a synergetic effect, which implies that farmers are best served by taking up the full set of SRI components. However, many SRI proponents have strongly resisted the notion that SRI is a fixed technology or technological package. A prime reason for this is to avoid comparisons with the 'technology packages' of the Green Revolution, which incorporated improved seeds, fertiliser and irrigation. To escape this association, the term 'technology' is mostly avoided in the SRI 
literature, where authors prefer terms such as 'strategy', 'principles' or 'methodology' (e.g. Uphoff, 1999, 2003).

For any technology to travel successfully from one setting to another requires a distillation of its key features into a simplified form. Latour (1987) called this the creation of an 'immutable mobile', making the point that it is the logistics of distribution rather than the conception in offices or laboratories that determine the ultimate success or failure of science and technology. This was done with the agro-ecological principles of SRI that Henri de Laulanié developed, which were simplified and codified into a list of component practices for easier communication and translation, so that they could be carried to new sites. The packaging of the SRI principles is what makes the method distinctive, recognizable and transferable from one site to another (Glover, 2011a).

However, a technology package is not completely immutable, since in fact it needs to be unpacked and reconfigured to make it work in new places (Glover et. al., 2017). The fact that farmers can select from among the principles, and adapt each of the component practices to suit their own circumstances, enables rather than obstructs the transferability of the SRI package. But the decomposability of SRI has led to disputes and confusion over the question of when a farmer or community can be said to have 'adopted' the new method. Numerous field studies have confirmed that farmers rarely adopt all the SRI principles (Glover, 2011b and 2011c; Noltze et al., 2012; Ly et al., 2012; Palanisami et al., 2013; Sen, 2015). Critics complain that this kind of flexible application of the SRI principles by farmers makes it nearly impossible to assess the spread of SRI, and therefore all claims about its wide distribution are hard to verify. In recent years SRI promotion materials tend to put more emphasis on flexible adaptation (Glover, 2014), thereby not only acknowledging the way farmers seem to adapt the SRI principles but at the same time making it hard to specify what counts as an 'SRI field' or 'SRI farmer'. In this respect the SRI phenomenon and its supporters seem to challenge another core value among crop scientists and agricultural extension agencies, often labelled as 'diffusion', 'scaling-up' or 'impact'.

Our point in this section is that myth-like attributes are bestowed on technologies though they have little to do with the technical features of 
the technology itself. Mythical attributions are an effect of the interactions between development narratives and technology. SRI acquired these features (with both positive and negative aspects) largely because its story of success - i.e. the spread of a technology delivering high yields through a synergetic combination of several technical components - touched upon core narratives of agronomic research for global development and food security. This made its claims sensitive and therefore they were contested. As a consequence, SRI's profile as a technopolitical mythology grew. In particular, SRI came to be understood as a 'controversial technology' propelled from below by grassroots activism and NGOs, but resisted by the incumbent powers of agricultural science. These narrative trajectories, populated by heroes and villains, are often attached to science-based agricultural improvements, including the mentioned example of IR8, 'miracle rice'. Another, more recent example, with dynamics very similar to SRI, is Conservation Agriculture (Andersson and Giller, 2012; Giller et.al., 2009).

\section{Technological change and myth}

Myths have a practical function, not just as stories but as cultural tools. Myths, through language, have an impact on everyday situations and human action (Weiner, 1994). They provide guidelines for understanding events and dealing with unfamiliar situations. Rather than reproducing and stabilising the status quo, a myth works through narrative to rationalise disturbances in everyday life and provide incentives for people not to dismiss change. Myths thus play a somewhat paradoxical role of maintaining social order by challenging the tendency to accept things just as they are.

"Each story provides an insight, an oblique and novel perspective that disabuses us from the normal, everyday habit of taking our world, our descriptions of it, our way of acting in it, and our beliefs as true, natural and self-evident" (Weiner, 1994: 593; cf. Kuper, 1999).

This perspective on myth allows anthropologists to observe how communities create linkages between supra-natural cosmology, occasions of mythical story-telling or rituals that refer to this cosmology, and 
practical events. By the retelling of a mythical story and through the enactment of rituals, linkages are established between myth and everyday practice.

The introduction of new technological options disrupts existing routines. Development narratives are like myths, which put this disruption into a particular perspective, making it acceptable and even desirable (Roe, 1991). Development narratives share with myths a broad cosmological perspective and an outspoken moral orientation. The general structure of myths is typically a binary storyline presenting one or more linked opposites (Kuper, 1999; Prince, 2003: 56). In the case of technology the binary choice is either to reject the technological change, which leads to destruction and misery, or to embrace the innovation, which leads to prosperity and wellbeing.

What are the overarching mythological narratives underlying the SRI claims, leading some to consider it magic and others to call it blasphemy? We identify two such narratives. The first is the food security narrative. This storyline portrays population growth as a threat to humanity, leading inevitably to mass starvation unless serious action is undertaken to secure appropriate quantities of food. This Malthusian narrative was given a hopeful response in the twentieth century, when economists and ecologists argued that suitable policies and programmes could prevent population growth from leading to food scarcity. This line of thinking was tied to development and agricultural research through the Rockefeller Foundation's Mexican Agricultural Program in the 1940s (Perkins, 1997; Harwood, 2012). In the same period, population growth and food scarcity were being linked to another major threat of that time, Communism, felt most acutely in Asia. India was a top priority for the Rockefeller Foundation and the American government to develop new programmes on food aid and agronomic research (Perkins, 1997: 138; Cullather, 2010: 135).

These programmes resulted in what came to be known as the Green Revolution. The connections between agricultural science, development policy and Cold War politics reinforced the narrative of food security as a national and global security issue. Unless the granaries were filled, political instability and Communist-inspired revolt would destroy nations and shift the Cold War balance of power. Technological change addressing food 
security therefore became a national security issue suitable for strong government intervention. To gain traction in this area, governments required standardised quantitative units (Porter, 1995). Technocrats including physicians and economists:

"conceptually rolled all commodities, all farms into one big farm and all markets into an aggregate national or even world market, as if all people were drawing provisions from a single larder" (Cullather, 2010: 13).

The calorie became the main unit for food security assessment, while for farm output the net weight of production per farm unit, in metric tons per hectare, became the standard. These administrative indices became prime measures for evaluating the success of technological change in agriculture.

The prioritisation of plant breeding within the Green Revolution, to increase crop yields and farm output, was deemed the right kind of technological change to respond to the food security narrative. It was through increasing food production, much more than the humanitarian narrative of poverty alleviation, that the Green Revolution could claim its major successes (Cullather, 2010; Harwood, 2012). The assertion that SRI cultivation methods are capable of producing very high rice yields clearly addresses the food security narrative, and as such it represented a challenge to agronomic researchers working on competing technologies (Glover, 2014). In India, as in some other countries, this narrative about yields (and hence food security) seemed to attract at least some support for SRI from policy makers and donors. Newspapers and other media enthusiastically relayed reports of high yields in areas of India where SRI had been introduced (Basu and Leeuwis, 2012).

A second narrative associated with SRI concerns sustainable agriculture and agro-ecology. This narrative is often associated with social movements that reacted against the kinds of industrial agriculture promoted by the Green Revolution. However, this narrative also has a broader basis in science, policy and private industry networks, connected by 'green knowledge' (Jamison, 2001). Early versions of the sustainability narrative can be traced back to the early twentieth century, when several ecological ideas about farming emerged (Harwood, 1990). Developments in agro- 
ecology research, in particular the emergence of systems ecology, contributed to the (contested) idea that ecologies developed towards an equilibrium and that human intervention could help to achieve and sustain a steady state (Kwa, 1987).

Smallholder farmers typically work within tight ecological constraints, striving to ensure that the returns to their labour and other inputs provide an acceptable livelihood. Sustainable agriculture is not only about preserving the ecological integrity of a system but also diminishing any negative effects of uncontrollable changes in the costs of external inputs or the prices of farm products (Netting, 1980). In its mythological form, the key lesson of this narrative is that taking excessive risk by overexploiting resources, or relying too heavily on external inputs, leads to misfortune in the long run. However, translating this narrative into clearly defined and measurable units is very difficult. Agro-ecological researchers typically work with models that incorporate a variety of input factors and conceive outcomes as emergent properties of systemic processes rather than straightforward input-output ratios (Tittonell, 2014). The unit of analysis may be 'a farm', but typically is the more abstract 'farming system' which refers to a certain abstracted notion of farming based on a particular matrix of inputs and contextual conditions.

The farming systems perspective makes the sustainable agriculture narrative particularly interesting for researchers and practitioners who work with farming communities. In place of a singular focus on crop yield, a diverse range of farm innovations, ecological factors and livelihoods concerns may be experimented with, tested and promoted. For policy makers the sustainable agriculture narrative offers a wider scope for intervention. Nonetheless, policy goals are typically expressed in terms of crop yields or economic measures such as costs and profits. Although such reductions are at odds with the agro-ecologists' narratives of sustainable agriculture, they may have to be accepted in order to fit into policy agendas or show that sustainability can contribute directly to food security. The framing of the synergetic interactions claimed to operate within SRI illustrates this pragmatic accommodation to prevailing policy and bureaucratic concerns about yield and food security, encapsulated in slogans that emphasise productive efficiency such as "producing more with less" or "more crop per drop" (Sinha et al., 2007; Uphoff et al., 2009). 
Within activist and NGO networks, however, the sustainable agriculture narrative is an important motivation for promoting SRI. For example, organisations such as Watershed Support Services and Activities Network (WASSAN, Secunderabad, Telangana) and the People's Science Institute (PSI, Dehradun, Uttarakhand), two major NGOs that promote SRI in India, do so within a strategic framework that emphasises the sustainable use of human and natural resources to improve the livelihoods of the rural population.

The disputes about SRI can be linked directly to these two overarching narratives. SRI became a vehicle for these competing development storylines, generating high expectations, keen attention and controversy. These associations dragged SRI into the realm of technopolitical mythology. Within this development narrative of SRI, the views and perspectives of farmers do not figure very prominently. In the next section we examine the contrasting ways in which mythological narratives shape SRI at the local level.

Local mythology: Scheduling transplanting dates and the ritual of Din Bar

The importance of rice in Asian countries is reflected in its appearance in many mythical and religious stories (Ohnuki-Tierney, 1994). In Hinduism, India's dominant religion, rice is prominent in the mythical tales of the goddess Lakshmi. Connections between these mythical stories and agricultural practice are created through the performance of rituals including those for land preparation, transplanting, post-transplanting, harvesting and post-harvesting (Sammadar, 2006: 114). Central in the case presented here is a transplanting ritual. The essential feature of the ritual is a decision about what day the rice season will officially start. This day, called Din Bar, initiates transplanting activities in the light of the availability of water. The introduction of SRI interfered with this ritual in three villages in the Himalayas of Uttarakhand: Phalenda, Thayeli and Dakhwangaon, where it was introduced from 2008 by PSI in cooperation with another NGO, the Mount Valley Development Agency (MVDA). This section of the paper is based on fieldwork carried out by the first author (D. Sen) in two consecutive rice cultivation seasons from 2011 to 2013. 


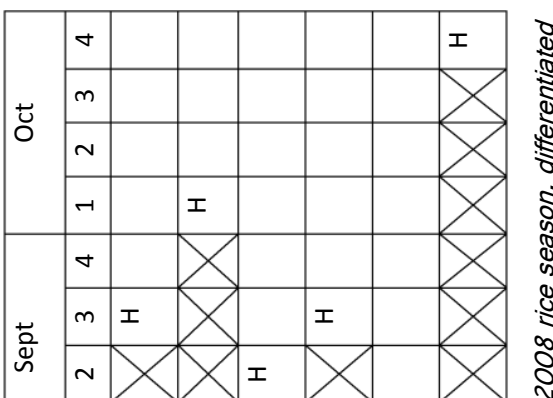

0
0
0
0
0
0
0
0
0
0
0
0
0
0
0
0

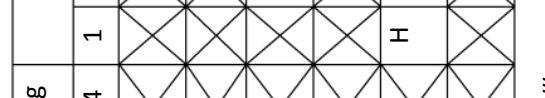

की $\frac{\text { के }}{2}$

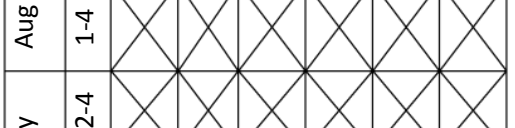

今

$\leqslant$ ज्ञ

Iิ ले

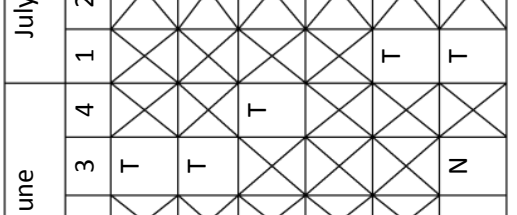

क

¿ 8

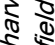

है के

हो

吾

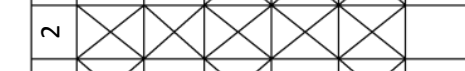

$\rightarrow \times 2 \times 1$

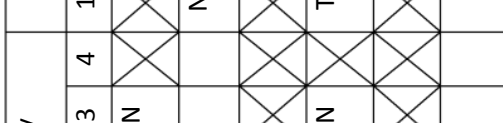

$\grave{\pi}$

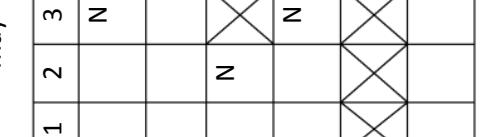

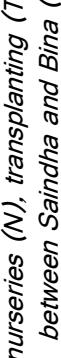

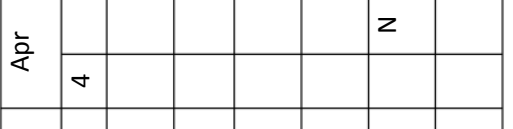

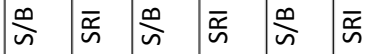

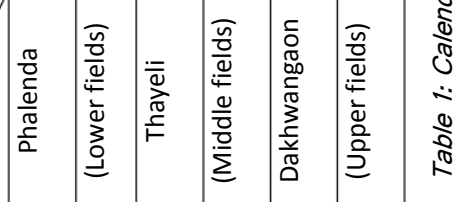


The day for Din Bar in each village is selected by the Gram Panchayat, the village council. The Gram Panchayat first checks with local farmers if they are ready to start field operations, beginning with transplanting. The village priest is then summoned to consult the Panchang, the Hindu almanac, to propose a suitable date. The common belief is that fixing the start of the season in this manner protects the crop from damage by natural disasters such as droughts, floods, storms, pests and diseases. Villagers who disregard the Din Bar ritual and start transplanting beforehand face social denunciation. Conventional seedling nurseries are established a couple of months before the expected date of Din Bar.

In 2008 MVDA initiated a first set of trials with SRI in 52 rice plots belonging to 25 farm households in the three villages. From late May to early June, trainers and farmers together constructed Raised Bed Nurseries (RBNs), in which seedlings are grown on pieces of ground that are raised and levelled slightly above the surrounding soil. The planting schedules that resulted from this activity are presented in Table 1. Fields where SRI methods were not applied were either transplanted with seedlings from other seedbeds or direct-seeded. Fields where seedlings were transplanted from seedbeds were termed Bina (Bijwad in Dakhwangaon), while directseeded rice fields were called Saindha. Creating seedbeds and direct sowing are done at approximately the same time. Saindha fields may also be used as a source of seedlings, which may be transplanted into other fields later on.

In Phalenda and Dakhwangaon the transplanting of all rice fields, including the SRI fields, was synchronised by the declaration of Din Bar. Since SRI requires very young seedlings, the RBNs for these fields had to be built and sown later. In Phalenda this was done around the first week of June rather than in April, in order to fit with the expected date of Din Bar. Farmers from Phalenda reflected on the consequences of this approach:

"Though there was profuse tillering in the SRI crop, it did not ripen along with our other rice crops. At the time of transplanting, SRI seedlings were just 8-12 days old whereas other seedlings were already 30-40 days old. Therefore the grains of the SRI crop matured late, and they were subject to damage by stray livestock and monkeys. If SRI seedlings could have been transplanted 15-20 days earlier, we could have got higher grain production 
with increased yields" (Focus Group Discussions, Phalenda, 15 July, 2011).

In Dakhwangaon the RBNs were established in the third week of June and transplanting commenced after Din Bar (30th June 2008). By that time, the SRI seedlings were only a couple of weeks old whereas the conventionally raised seedlings had been growing for more than two months. As a result, the rice from SRI fields was harvested almost two months later than normal. This had a negative impact on the rice yields from SRI plots. By late September and early October temperatures in the higher mountain areas, where Dakhwangaon is located, drop quite quickly and delay the ripening of the rice crop. Some of the SRI paddy did not ripen at all.

In Thayeli the MVDA staff took a different approach. They proposed to advance the date of Din Bar for SRI fields. The RBNs for the SRI plots were established in the third week of May. Thirteen of the participating 18 households in Thayeli transplanted from their RBNs during the first week of June, ahead of Din Bar (25th June 2008). The farmers recalled that grain yields from SRI plots that year were much higher than on conventional plots.

In the second year of SRI, farmers in Phalenda also decided to establish RBNs earlier, around mid-May. They transplanted the 10- to 15-days-old seedlings before Din Bar, which was set for 20 June 2009. During the season, excessive rainfall damaged the crop in several fields. This misfortune was blamed by the community on the early transplanting of SRI fields. Villagers felt that disregarding Din Bar in the future could bring more disaster. However, rather than reverting to conventional practice, the villagers decided to observe two separate rituals, establishing one Din Bar for SRI fields (around the end of May) and another Din Bar for the other fields. In this way the harvest period for both cultivation methods, rather than the transplanting period, was synchronised. A second innovation was that the responsibility of consulting the village priest to fix the date for the new SRI Din Bar was taken up by the Village-Level Resource Person (VLRP) rather than the Gram Panchayat. The VLRP was a leading SRI farmer in the community, appointed to work with the MVDA as the principal contact person in the village. The inauguration of a second Din Bar ritual was not 
uncontested. In Phalenda there is a rather high proportion (about 40 per cent) of unirrigated (rainfed) fields used for crops other than rice, despite a perennial canal irrigation system. These fields require the farmers' full attention at the start of the season. Objections against the creation of another festive day came primarily from households farming the unirrigated fields. By 2012, 60 out of 113 resident farm households in Phalenda had practised SRI methods on at least one field in at least one year.

In Thayeli the situation was different. From 2009 onwards, farmers completely abandoned the Din Bar ritual. They synchronised the sowing of all nurseries and Saindha fields around mid-May, and began transplanting young seedlings from RBNs in the last week of May. Thayeli has a smaller number of unirrigated plots and the continuous availability of canal water facilitated the early transplanting of young seedlings from RBNs. Many of the farm households practising SRI methods in Thayeli also began to thin out the seedlings in their direct-seeded Saindha fields at the same time as they transplanted their young RBN seedlings for SRI. This meant that the thinning of the Saindha fields and the transplanting of seedlings from Saindha plots into additional rice plots were also completed earlier than in the past, which allowed the farm households to complete their land preparation and transplanting operations in one go. Since the farmers had not observed any adverse effects on grain yields or any other negative signs, they felt it was no longer necessary to consult the village priest to arrange the Din Bar ritual. Other rituals related to farm operations, such as Koali Din which marked the start of harvesting, were not abandoned. Farmers in Thayeli expressed an overall satisfaction with SRI:

"Increased grain yields in the very first year of SRI motivated us to give up Din Bar in the second year. Before we used to do transplanting from Saindha, and weeding used to take a lot of our time. All of us therefore readily agreed to convert our plots under SRI" (Focus Group Discussions, Thayeli, 20 July, 2011).

Dakhwangaon is situated at a higher elevation, where the season in which rice can be grown is shorter, due to lower temperatures. At the beginning of the season there is not enough water to serve all the fields. Rice fields located farther away from the homestead are direct-seeded (Saindha). For most of the other rice fields, seedlings are kept in the 
nursery for an extended period and transplanted when they are much older, once the availability of water has improved. The restricted availability of water at the beginning of the season excludes the option of transplanting young seedlings for most of the rice fields. Farmers explained:

"We can neither go for early transplanting nor establish RBNs later, as the crop won't ripen. Since our village is located at a higher altitude it gets cold here earlier. For two years [2009 and 2010], some of us kept on trying to transplant young seedlings after Din Bar without success. The next year we just took [older] seedlings from Saindha and transplanted them at wider spacing after the Din Bar, and the crop ripened at the right time. This is how we adjusted according to our situation" (Focus Group Discussions, Dakhwangaon, 28 July 2011).

Forty out of 60 farm households in Dakhwangaon tried SRI, but most of these transplanted older seedlings taken from Saindha fields or conventional seedbeds after the announcement of Din Bar. Only two farmers sowed RBNs in the first half of May and transplanted early, before Din Bar. Elderly farmers of the village expressed their discontent about this, but overall SRI was not dismissed as bad practice. These adjustments in Dakhwangaon basically reduced the original set of SRI principles to the transplanting of older seedlings, spaced more widely than in traditional practice.

The changes to the institution of Din Bar in Phalenda, Thayeli and Dakhwangaon are summarised in Table 2. The farmers in the three Himalayan villages did not assess SRI on the basis of straightforward productivity measurements. Farmers certainly value yields for food security and the production of a marketable surplus. They are experienced in allocating scarce resources and inputs to achieve an acceptable output from their rice fields. However, an equally important value in this situation is the coordination of farm operations across a community of neighbours. Many of the adjustments made in the sowing and transplanting activities were introduced in order to better coordinate the efforts of groups of farmers. In doing so, the farmers treated the SRI methods, to which they were introduced by MVDA, not as a fixed technological package but as a set of options or propositions that added to the existing range of ways of 
growing rice in their community. In the process, the traditional rituals and conventional rhythms of farming were readily adjusted and revised with considerable flexibility, to accommodate new technical practices and suit changing circumstances.

\begin{tabular}{|c|c|c|c|c|c|c|}
\hline \multirow{2}{*}{} & \multicolumn{3}{|c|}{ Phalenda } & \multicolumn{2}{c|}{ Thayeli } & \multicolumn{2}{c|}{ Dakhwangaon } \\
\cline { 2 - 7 } & Saindha/Bina & SRI & Saindha/Bina & SRI & Saindha/Bina & SRI \\
\hline 2008 & 17 June & - & 25 June & - & 30 June & - \\
\hline 2009 & 20 June & - & - & - & 2 July & - \\
\hline 2010 & 18 June & $\begin{array}{c}30 \\
\text { May }\end{array}$ & - & - & 29 June & - \\
\hline 2011 & 13 June & $\begin{array}{c}2 \\
\text { June }\end{array}$ & - & - & 15 June & - \\
\hline 2012 & 11 June & $\begin{array}{c}29 \\
\text { May }\end{array}$ & - & - & 18 June & - \\
\hline
\end{tabular}

Table 2: Dates of traditional and SRI-related Din Bar in three villages for five seasons.

\section{Conclusion}

Story telling is an important means of expressing hope and belief in a better future. Technology often features in such stories as a means of bringing about that better future. We have argued that such projections onto technology have mythological characteristics. Technologies are often portrayed as simple solutions to problems which, in reality, have complex socio-economic and institutional causes as well as technical aspects. We have suggested that a technical fix, that is, an attempt to solve complex social-economic problems with a single technical innovation, contributes to controversies around technological options such as SRI. SRI has been contested partly because the narratives to which it has been attached (food security, agro-ecology) evoke sensitive values close to the heart of agriculture-for-development narratives. Three of these core values are prominent in the SRI debate. First, the contestation over yield claims relates to the core narrative about global food security, which in 
its mythological aspects relates to Malthusian concerns about the relationship between population, food production, and hunger. The second controversial issue concerns the claim of synergetic effects, which addresses the overarching narrative of sustainable agriculture and overlaps with wider contestations around agro-ecology. The mythological form of this storyline relates to resource scarcity and resource-use efficiency, and the risks of depending on external inputs. The third topic of contestation concerns the distribution of SRI and contested claims about how many farmers have adopted the new method. The mythological development narrative behind this story concerns the need to achieve impact at scale if moral obligations are to be fulfilled and disaster is to be avoided.

Development narratives typically reduce technology conceptually to a discrete, self-sufficient, transferable package. The distillation of technology into a concise list of inputs and prescribed methods serves to make the technology mobile and also assists policy makers to trace its spread and measure its impact. However, the messy reality of development or farming practice, which we illustrated with evidence from the three case study villages in the Himalayas, means that there is no immediate or even steady adoption of SRI as a whole package. The farmers and communities in each village adapted their rice cultivation methods in ways that deviated from the formal guidelines they were given, which were also distinct from the variations of SRI practised in the other two villages. The case material also showed how the changes to cultivation practices were linked to religious mythology, as expressed in the ritual to settle a date for Din Bar. The underlying purpose of these ritual practices is to safeguard important community values including successful harvests and the long-term survival of the community. The rituals help to synchronise farming activities across the community in order to ensure that crops are sown and harvested at propitious times. Such rituals are not merely cultural epiphenomena but relate to the same kinds of storylines as in global development discourse concerning the values of food security, agro-ecological sustainability, and the distribution of burdens and benefits across the community. At both local and global levels, ritual practices and mythological narratives function as important tools for development. It is a mistake, however, to imagine that global concerns may be translated directly into local practices through magical beliefs about the dissemination of technology packages. 


\section{Bibliography}

ANDERSSON J.A. and GILLER K.E., 2012, "On heretics and God's blanket salesmen: contested claims for Conservation Agriculture and the politics of its promotion in African smallholder farming", in SUMBERG J. and THOMPSON J. (eds.), Contested agronomy. Agricultural research in a changing world, London, Earthscan: 22-46.

BASU S. and LEEUWIS C., 2012, "Understanding the rapid spread of System of Rice Intensification (SRI) in Andhra Pradesh: Exploring the building of support networks and media representation", Agricultural Systems, 111: 34-44.

BERKHOUT E. and GLOVER D., 2015, "On-farm impact of the System of Rice Intensification (SRI): Evidence and knowledge gaps", Agricultural Systems, 132: $157-166$.

CULLATHER N., 2010, The hungry World: America's Cold War Battle against Poverty in Asia, Cambridge MA, Harvard University Press.

DOUGLAS M., 2002 [1966], Purity and Danger. An analysis of concept of pollution and taboo, London and New York, Routledge Classics Edition.

DUWAYRI M., TRAN D.V. and NGUYEN V.N., 2000, "Reflections on yield gaps in rice production: how to narrow the gaps", in PAPADEMETRIOU M.K., DENT F.J., HERATH E.M. (eds.), Bridging the yield gap in the Asia-Pacific region, Bangkok, FAO Regional Office for Asia and the Pacific. Available online at: http://www.fao.org/DOCREP/003/x6905e/x6905e05.htm

GILleR K.E., WITTER E., CORBEelS M. and TITTONELL P., 2009, "Conservation agriculture and smallholder farming in Africa: the heretics" view", Field Crops Research, 114(1): 23-34.

GLOVER D., 2011a, "A system designed for rice? Materiality and the invention/discovery of the System of Rice Intensification", East Asian Science, Technology and Society, 5(2): 217-237.

GLOVER D., 2011b, "Science, practice and the System of Rice Intensification in Indian agriculture", Food Policy, 36(6): 749-755.

GLOVER D., 2011c, "The System of Rice Intensification: Time for an empirical turn", NJAS-Wageningen Journal of Life Sciences, 57(3-4): 217-224.

GLOVER D., 2014, "Of yield gaps and yield ceilings: Making plants grow in particular places", Geoforum, 53: 184-194. 
GLOVER D., VENOT J.-P. and MAAT H., 2017 (forthcoming), "On the movement of agricultural technologies: Packaging, unpacking and situated reconfiguration", in SUMBERG J., ANDERSSON J. and THOMPSON J., Agronomy for Development: The Politics of Knowledge in Agricultural Research, London, Earthscan.

HARWOOD J., 2012, Europe's Green Revolution and Others Since: the Rise and Fall of Peasant-Friendly Plant-Breeding, London, Routledge.

HARWOOD R.R., 1990, "A History of Sustainable Agriculture”, in EDWARDS C.A., LAL R., MADDEN P., MILLER R.H., HOUSE G. (eds.), Sustainable Agricultural Systems, Boca Raton, St. Lucie Press: 3-19.

JAMISON A., 2001, The Making of Green Knowledge: Environmental Politics and Cultural Transformation, Cambridge, Cambridge University Press.

KASSAM A., STOOP W. and UPHOFF N., 2011, "Review of SRI modifications in rice crop and water management and research issues for making further improvements in agricultural and water productivity", Paddy and Water Environment, 9(1): 163-180.

KUPER A., 1999, Culture: the Anthropologists' Account, Cambridge MA and London, Harvard University Press.

KWA C., 1987, "Representations of Nature Mediating between Ecology and Science Policy: The Case of the International Biological Programme", Social Studies of Science, 17(3): 413-442.

LABORTE A.G., DE BIE K., SMALING E.M.A., MOYA P.F., BOLING A.A. and VAN ITTERSUM M.K., 2012, "Rice yields and yield gaps in Southeast Asia: Past trends and future outlook", European Journal of Agronomy, 36(1): 9-20.

LANSING J.S. and Clark W.C., 2009, Priests and Programmers: Technologies of Power in the Engineered Landscape of Bali, Princeton, NJ, USA, Princeton University Press.

LATOUR B., 1987, Science in Action: How to Follow Scientists and Engineers through Society, Milton Keynes, Open University Press.

LAULANIÉ H. DE, 1993, "Le système de riziculture intensive Malgache", Tropicultura, 11: 1-19.

LY P., JENSEN L.S., BECH BRUUN T., RUTZ D. and DE NEERGAARD A., 2012, "The System of Rice Intensification: Adapted practices, reported outcomes and their relevance in Cambodia", Agricultural Systems, 113: 16-27. 
MAAT H. and GLOVER D., 2012, "Alternative configurations of agronomic experimentation", in SUMBERG J. and THOMPSON J. (eds.), Contested agronomy. Agricultural research in a changing world, London, Earthscan: 131-145.

NETTING R.M., 1993, Smallholders, Householders: Farm Families and the Ecology of Intensive, Sustainable Agriculture, Stanford CA, Stanford University Press.

NOLTZE M., SCHWARZE S. and QAIM M., 2012, "Understanding the Adoption of System Technologies in Smallholder Agriculture: The System of Rice Intensification (SRI) in Timor Leste", Agricultural Systems, 108(0): 64-73.

OHNUKI-TIERNEY E., 1994, Rice as Self: Japanese Identities through Time, Princeton, Princeton University Press.

PALANISAMI K., KARUNAKARAN K.R., AMARASINGHE U. and RANGANATHAN C.R., 2013, “Doing Different Things or Doing It Differently? Rice Intensification Practices in 13 States of India", Economic and Political Weekly, XLVIII(8): 51-58.

PERKINS J., 1997, Geopolitics and the Green Revolution: Wheat, Genes and the Cold War, New York, Oxford University Press.

PORTER T.M., 1995, Trust in Numbers: The Pursuit of Objectivity in Science and Public Life, Princeton, Princeton University Press.

PRASAD C.S., 2009, "Conversations on knowledge and democracy: fables from SRI", Seminar, 597: 2-6.

PRINCE G., 2003, A Dictionary of Narratology (Revised Edition), Lincoln and London, University of Nebraska Press.

RAFARALAHY S., 2002, "An NGO Perspective on SRI and its Origins in Madagascar", in UPHOFF N., FERNANDES N., LONGPING Y., JIMING P., RAFARALAHY S. and RABENANDRASANA J. (eds.), Assessments of the System of Rice Intensification (SRI), Proceedings of an International Conference held in Sanya, China, April 1-4, 2002, Ithaca, NY, Cornell International Institute for Food, Agriculture and Development: 17-23.

ROE E.M., 1991, “Development Narratives, Or Making the Best of Blueprint Development", World Development, 19(4): 287-300.

SAMADDAR A., 2006, "Traditional and Post traditional: A Study of Agricultural Rituals in Relation to Technological Complexity among Rice Producers in Two Zones of West Bengal, India", Culture and Agriculture, 28(2): 108121. 
SCOTT D., 2011, "The Technological Fix Criticisms and the Agricultural Biotechnology Debate", Journal of Agricultural and Environmental Ethics, 24(3), 207-226.

SEN D., 2015, "How Smallholder Farmers in Uttarakhand Reworked the System of Rice Intensification: Innovations from Sociotechnical Interactions in Fields and Villages", Wageningen, PhD thesis Wageningen University, 200 p.

SHEEHY J.E., SINCLAIR T.R. and CASSMAN K.G., 2005, "Curiosities, nonsense, nonscience and SRI", Field Crops Research, 91(2-3): 355-356.

SINCLAIR T.R. and CASSMAN K.G., 2004, "Agronomic UFOs", Field Crops Research, 88: 9-10.

SINHA S.K. and TALATI J., 2007, "Productivity impacts of the system of rice intensification (SRI): A case study in West Bengal, India", Agricultural Water Management, 87(1): 55-60.

STIRLING A., 2008, “'Opening Up' and 'Closing Down': Power, Participation, and Pluralism in the Social Appraisal of Technology", Science, Technology and Human Values, 33(2): 262-294.

STOOP W., UPHOFF N. and KASSAM A., 2002, "A review of agricultural research issues raised by the system of rice intensification (SRI) from Madagascar: Opportunities for improving farming systems for resource-poor farmers", Agricultural Systems, 71: 249-274.

STONE G.D., 2002, "Both Sides Now: Fallacies in the Genetic-Modification Wars, Implications for Developing Countries, and Anthropological Perspectives", Current Anthropology, 43(4): 611-630.

SURRIDGE C., 2004, “Feast or famine?”, Nature, 428(6981): 360-361.

THAKUR A.K., UPHOFF N. and ANTONY E., 2009, "An assessment of physiological effects of System of Rice Intensification (SRI) practices compared with recommended rice cultivation practices in India", Experimental Agriculture, 46(1): 77-98.

TITTONELL P., 2014, “Ecological intensification of agriculture: Sustainable by nature", Current Opinion in Environmental Sustainability, 8: 53-61.

UPHOFF N., 1999, "Agroecological implications of the System of Rice Intensification (SRI) in Madagascar", Environment, Development and Sustainability, 1(3-4): 297-313. 
UPHOFF N., 2003, "Higher yields with fewer external inputs? The System of Rice Intensification and potential contributions to agricultural sustainability", International Journal of Agricultural Sustainability, 1: 38-50.

UPHOFF N., 2013, "Rethinking the concept of 'yield ceiling' for rice: Implications of the System of Rice Intensification (SRI) for agricultural science and practice", Journal of Crop and Weed, 9(1): 1-19.

UPHOFF N., ANAS I., RUPELA O.P., THAKUR A.K. and THIYAGARAJAN T.M., 2009, "Learning about positive plant-microbial interactions from the System of Rice Intensification (SRI)", Aspects of Applied Biology, 98: 29-53.

UPHOFF N., FASOULA V., ANAS I., KASSAM A. and THAKUR A.K., 2015, “Improving the phenotypic expression of rice genotypes: Rethinking 'intensification' for production systems and selection practices for rice breeding", The Crop Journal, 3: 174-189.

WEINER J.F., 1994, "Myth and metaphor", in INGOLD T. (ed.), Companion Encyclopedia of Anthropology, London and New York, Routledge: 591612.

\title{
Miviviv
}

\author{
Debashish Sen is Director \\ People's Science Institute (Uttarakhand, India) \\ E-mail : debu_manu@yahoo.co.in
}

Harro Maat is Assistant Professor

in the History and Sociology of Agricultural Technology

Knowledge, Technology and Innovation Group, Wageningen University (The Netherlands)

E-mail : harro.maat@wur.nl

Dominic Glover is Fellow in International Development Studies

Institute of Development Studies, University of Sussex (Brighton, UK)

E-mail : d.glover@ids.ac.uk 
C. Shambu Prasad is Professor in Sociology of Knowledge Institute of Rural Management Anand (IRMA) (Gujarat, India)

E-mail : shambu@irma.ac.in 